\title{
A new method to simulate the hydrological state of soil under natural conditions
}

\author{
Anna-Katharina Wild ${ }^{(1)}$, Michael Thomas Marx ${ }^{(1)}$ and Gerhard Eisenbeis ${ }^{(1)}$
}

\author{
(1)Johannes Gutenberg University, Institute of Zoology, Department IV, Soil Zoology and Ecology, Becherweg 13, 55099 Mainz, Germany. \\ E-mail: annawild@students.uni-mainz.de,marxm1@students.uni-mainz.de,geisenbe@uni-mainz.de
}

\begin{abstract}
Micro, macro and mesofauna in the soil often respond to fluctuating environmental conditions, resulting in changes of abundance and community structure. Effects of changing soil parameters are normally determined with samples taken in the field and brought to the laboratory, i.e. where natural environmental conditions may not apply. We devised a method (STAFD - soil tubes for artificial flood and drought), which simulates the hydrological state of soil in situ using implanted cores. Control tubes were compared with treatment tubes in which floods of 15, 30, 60 and 90 days, and droughts of 60,90 and 120 days were simulated in the field. Flooding and drought were found to reduce number of individuals in all soil faunal groups, but the response to drought was slower and not in proportion to the expected decrease of the water content. The results of the simulated floods in particular show the value of the STAFD method for the investigation of such extreme events in natural habitats.
\end{abstract}

Index terms: climate change, drought, flooding, soil invertebrates, soil tubes, STAFD method.

\section{Um novo método para simular o estado hidrológico do solo em condições naturais}

\begin{abstract}
Resumo - As micro, macro e mesofaunas no solo respondem frequentemente à variação das condições ambientais, o que resulta em alterações na abundância e na estrutura da comunidade. Os efeitos das alterações nos parâmetros do solo são normalmente determinados com amostras recolhidas no campo e trazidas ao laboratório, ou seja, onde as condições ambientais naturais podem não ser aplicáveis. Criamos um método (STAFD - tubos de amostra de solo para inundações e secas artificiais), que simula o estado hidrológico do solo in situ com núcleos implantados. As amostras de controle foram comparadas com amostras de tratamentos em que foram simuladas inundações de 15, 30, 60 e 90 dias e secas de 60, 90 e 120 dias no campo. Verificouse que as inundações e a seca reduziram a quantidade de individuos em todos os grupos de fauna de solo, mas a resposta à seca foi mais lenta e não proporcional à redução prevista no teor de água. Os resultados das inundações simuladas demonstram, em especial, o valor do método STAFD para a investigação desse tipo de eventos extremos nos habitats naturais.
\end{abstract}

Termos para indexação: alteração climática, seca, inundação, invertebrados do solo, tubos de amostra de solo, método STAFD.

\section{Introduction}

Floodplains, either natural or seminatural, which commonly exhibit changes between flood and drought, are prime examples of sites with niche diversity and offer unique conditions and resources for both plants and animals. Such habitats have high conservation value and, due to the changing conditions, lead to high niche diversity. However, climate change may bring changes to the flow patterns of rivers. For example, in the case of the Rhine river it is predicted that in winter months the flow rate will increase, because of increasing temperatures and the lack of snowfall. In addition, due to the lack of snow melting, distinct spring floods will decrease, whereas the summer will be characterized by more severe droughts as temperatures rise and by the aperiodic occurrence of extreme precipitation events (Schär et al., 2004; Kundzewicz et al., 2005; Schröter et al., 2005). Therefore it is valuable to investigate the effects of altered moisture regimes on different soil indicator groups to predict changes in the soil community caused by these extreme weather conditions. Some effects of regular floods and droughts on different soil arthropods in Middle Europe have already been reported by Tamm (1986), Frampton et al. (2000) and Lindberg et al. (2002), but largely from laboratory studies. 
We report a new method to test artificial flood and drought events in the field, to get real information of the resilience of different soil organism groups with high accuracy. Further advantages include simplicity, low cost and minimal disturbance to the environment.

\section{Materials and Methods}

\section{Study site}

The study site, a part of the "Mainzer Becken", is situated in the Upper Rhine Rift $\left(8^{\circ} 05^{\prime} \mathrm{N}, 50^{\circ} 00^{\prime} \mathrm{E}\right.$, 82-84 m a.s.1.) in Germany. It is a typical seminatural and fragmented hardwood floodplain forest of the Northern Upper Rhine region (Ellenberg, 1996) with Quercus robur, Acer campestre, Fraxinus excelsior, Tilia cordata and Ulmus minor. The shrub layer is composed of Corylus avellana and Ribes rubrum, the underlayer consists of Anemone nemorosa, Allium ursinum, Aegopodium podagraria, Scilla bifolia and Hedera helix. The wooded area comprises a mosaic of small hillocks and depressions, which are subject to different moisture regimes. Since the extreme hot and dry summer of 2003 the depressions have been partially flooded twice, whereas the hillocks remained dry.
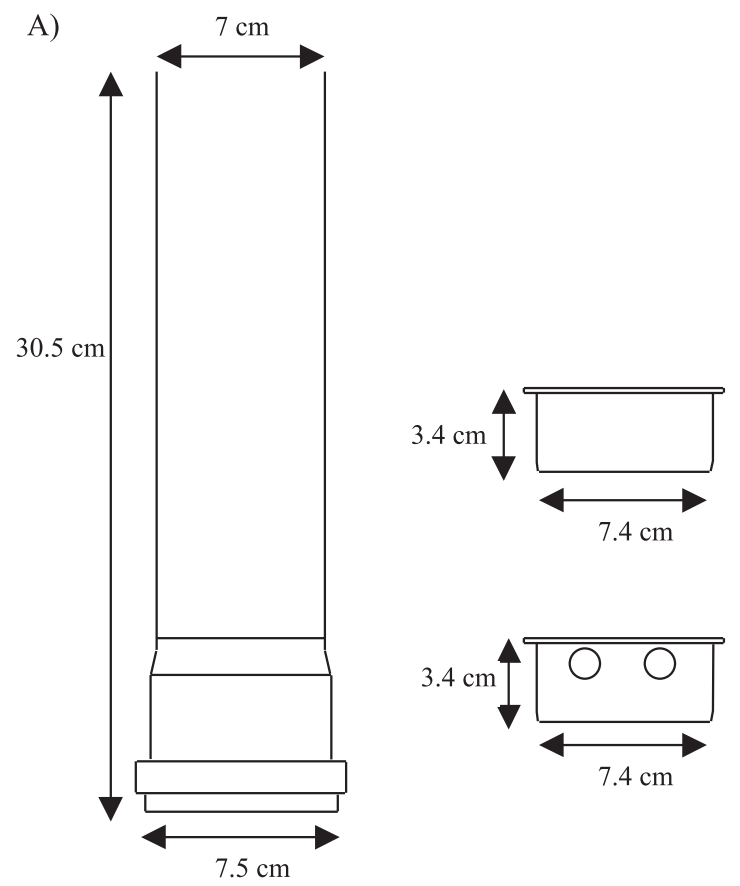

Figure 1. Dimensions of the STAFD tube, the close-fitting cap (top) and the laterally perforated cap (bottom), which protects the tube from rain-water infiltration but allows air circulation (A). Insertions of tubes for experimental simulation of flood and drought (B).
The herbaceous plant layer differs between the hillocks and depressions in this floodplain forest. The depressions are partially free of any plants, whereas the groundwater level varies along this characteristic mosaic for riparian forests (Ellenberg, 1996). This has a direct influence upon the upper soil layers in the depressions, whereas the hillocks are less influenced by groundwater. These differences are also reflected in the soil structure: the hillock soil structure has a greater amount of macropores when compared to the depression soil structure. The depressions have a high fraction of alluvial clay. Oxidation could be proved by ferric-manganese spots, indicating the influence of the high groundwater level.

\section{Soil tubes for the STAFD method}

For this investigation, we used commercial soil tubes (HT-Innenentwässerungsrohre, PVC, Marley Company, USA). The tubes had an overall length of $30.5 \mathrm{~cm}$, an upper diameter of $7.5 \mathrm{~cm}$, and a lower diameter of $7 \mathrm{~cm}$ (Figure $1 \mathrm{~A}$ ). The tube could be closed at the upper end by a close-fitting cap (diameter $7.4 \mathrm{~cm}$ ) (Figure 1 A), which prevented water loss and water ingress. To simulate flooding, tubes were filled up with a $20 \mathrm{~cm}$ preferably undisturbed soil core, and inserted narrow end upwards into the ground. the hillocks are covered with varied vegetation. Also,

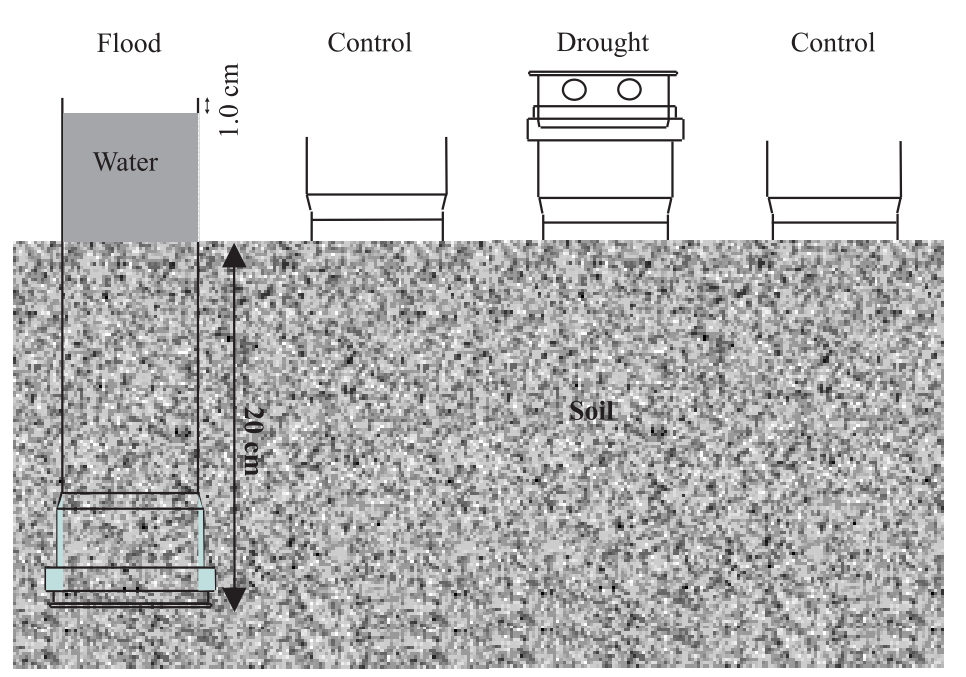


Water was added to $1 \mathrm{~cm}$ under the top of the soil tube (Figure $1 \mathrm{~B}$ ). For simulating drought, reversed soil tubes (wide end upwards) were implanted. Drought tubes were closed at the upper surface with a laterally perforated cap. This protected the tubes from rain water infiltration, but maintained air circulation and therefore aerobic conditions. The control soil tubes were left open at both ends and implanted parallel to the treatment tubes.

\section{Plot design}

Within a section of $1 \mathrm{~m}^{2}, 16$ soil tubes were implanted into the ground with a hammer. These 16 tubes represented one plot. Within every plot, four tubes were allocated for the extreme event "flood", four tubes for the extreme event "drought" and the respective accompanying eight controls. These different treatments comprising plot experiments were arranged parallel in four rows (Figure 2).

To obtain a representative transect across the floodplain forest, 20 plots were arranged in different places in the hardwood forest from the Rhine river towards the dam (Figure 2). Ten plots were located in two depressions and ten plots onto two hillocks. At each location, five plots were implanted in a 10-m distance. For the statistical analysis, the data obtained from the "flood-plots" of the hillocks and depressions were pooled. The "drought-plots" and the associated controls were treated similarly.

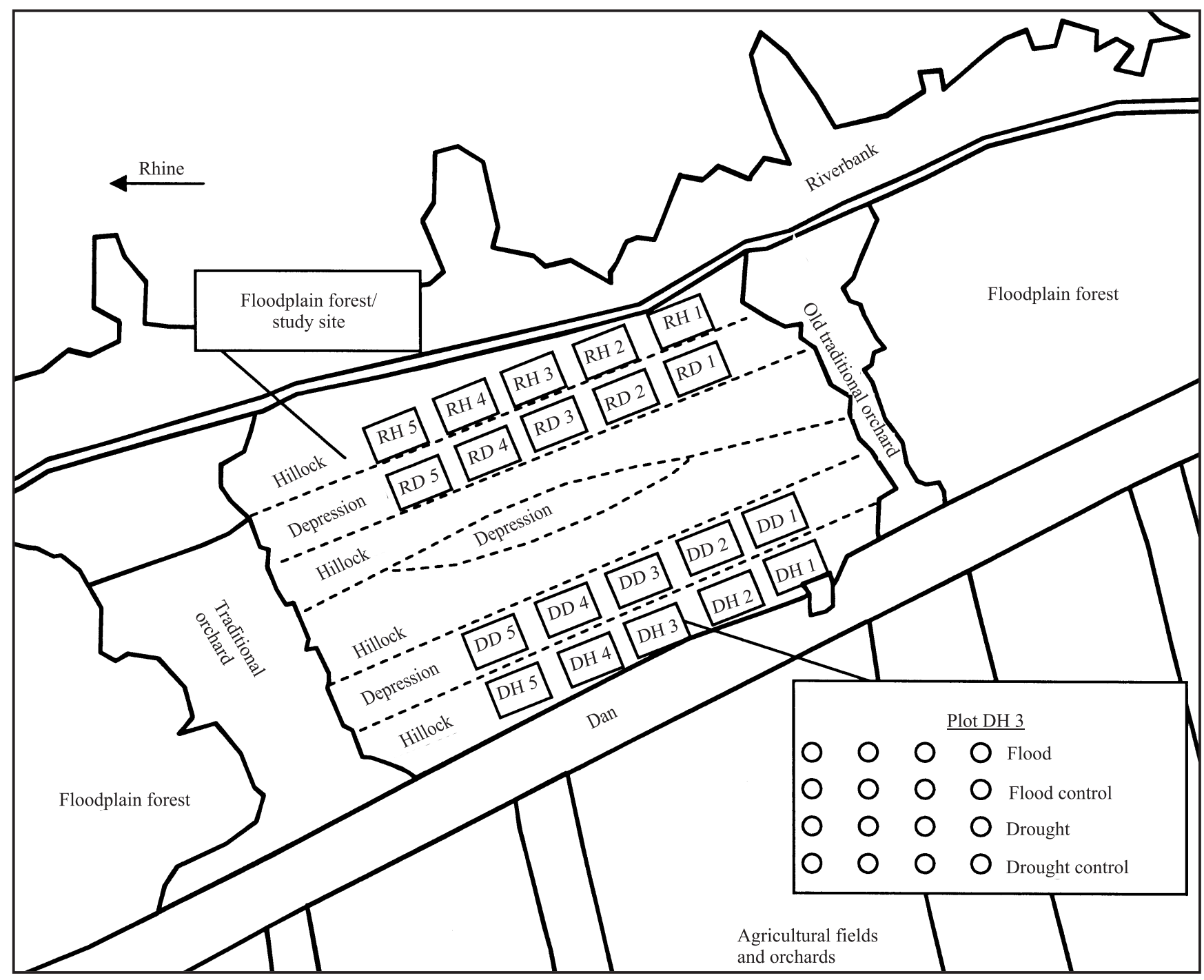

Figure 2. Plot design of the floodplain forest. RH, hillock near the Rhine river; RD, depression near the Rhine river; DH, hillock near the dam; DD, depression near the dam. 
To fill up the tubes with soil different strategies had to be used. For drought samples, the tubes were directly inserted into the study site. The drought tubes were closed at the top and the dehydration started. The control tubes were inserted likewise, but without being closed at the top and with no subsequent dehydration.

In contrast to the drought tubes, the tubes used to simulate flooding had to be closed at their lower end and thus another filling procedure was used. Soil was taken out of the plot with a spade and then backfilled into the tubes to resemble the natural soil profile. The filled tubes were then placed into the holes from which the soil was taken. Finally, the tubes were flooded with water from the Rhine river and refilled if the waterline decreased to $3 \mathrm{~cm}$ below the top of the soil tube. There are different reasons for this procedure. The hand filling of the flood tubes ensured that, irrespectively of the soil structure or composition, flooding of the tubes occurred only from the top and there was no risk of damaging the tube cap, and the soil structure was as close as possible to the one also that in situ present, after the filling of the tubes. Furthermore, in some sectors of the study site the soil is extremely loamy, and the water could only infiltrate the core sample if the soil were manually inserted into the tubes.

Different durations were applied to the flood and the drought sampling. The flood experiment was designed for a 90 -day period. This long duration was necessary to simulate an extraordinary extreme event for the soil organisms of the hardwood floodplain forest, where regular and periodic floods take no longer than about 30 days. One flood tube and the associated control were taken out of each of the 20 plots after 15, 30, 60 and 90 days respectively. The drought tubes were left out in the floodplain forest for 30,60, 90 and 120 days, respectively, as it was assumed that dehydration for more than 60 days effectively simulates the effects of an extreme dry period. The drought tubes were removed sequentially from the 20 plots in the same way as the flood tubes. The flood experiment took place from August to November 2007, the drought experiment from November 2007 to February 2008.

\section{Extraction method}

After recovering the flood tubes from the field, the water content of the soil cores was determined and the tubes were allowed to drain over a sieve for
12 hours (Adis, 1992). Soil animals were extracted from the flood tube contents using a modified Kempson extractor (Kempson et al., 1963) for 14 days $\left(25-55^{\circ} \mathrm{C}\right)$. Picric acid $(2-3 \%$ with detergent) was used as killing and fixing agent, and specimens were then transferred to $70 \%$ ethanol for storage and identification. The water content of the drought tubes was determined at two levels (top $5 \mathrm{~cm}$ and bottom $5 \mathrm{~cm}$ ). The Kempson extraction was inefficient for the drought samples, due to the dryness of the soil. Therefore, for these samples a wet sieve cascade was used (after Morris, 1922), again preserving specimens in $70 \%$ ethanol. Remaining sieved and wet soil was additionally extracted with the Kempson extractor following 30,60, 90 and 120 days of drought treatment, to account for egg hatching and emergence from dormant stages.

In this investigation, basic statistical analysis was done by comparing the "flood" and "drought" data with their respective controls. Due to the data distribution, comparisons of average numbers of individuals were performed with the nonparametric Mann-Whitney U-test (Statistica 6.1, StatSoft Incorporation, USA).

\section{Results and Discussion}

\section{Artificial flood experiment}

Figure 3 shows the total abundance of the frequent soil fauna groups of the hillocks and the depressions in the undisturbed control plots and after a simulated flood over the whole study period. Compared with the control plots, the number of individuals of all soil organism groups decreased. In the control, plots Isopoda, Diptera larvae, Coleoptera larvae, Diplopoda, Geophilomorpha, Lithobiomorpha, Lumbricidae, Pseudoscorpiones and Symphyla could be extracted consistently. Furthermore, isopods, symphylans and diplopods were the most dominant groups of the hillocks. However, with the exception of dipterous larvae only isopods were able to survive a long-lasting flood. Although the decrease of the isopods during the whole flood period was significant (Figure $3 \mathrm{~A}$ ), dipterous larvae showed similar abundances with only a low significant difference after 30 days in the flooded and the control plots. Except for the isopods and dipterous larvae, no other soil fauna survived the long-term flood simulation. Similar results were obtained by Rothenbücher \& 

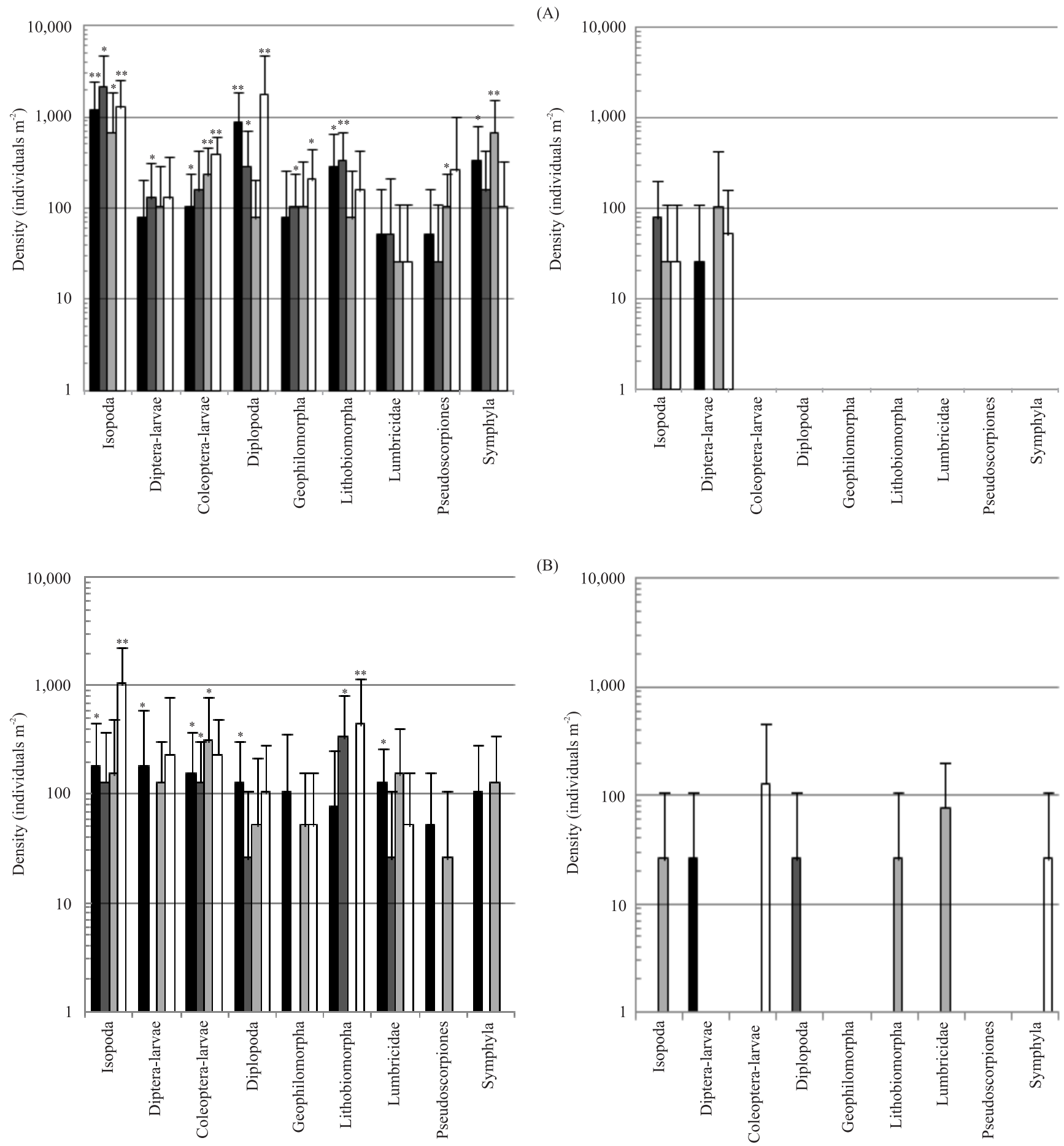

(B)

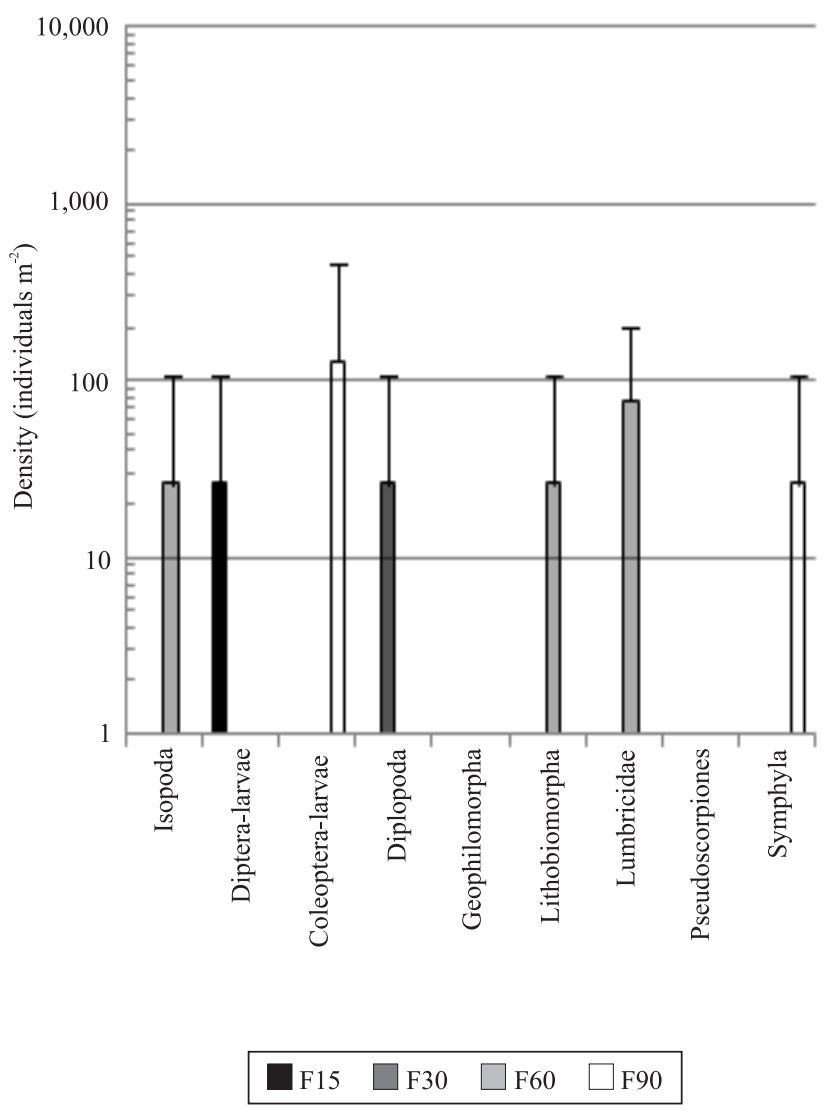

Figure 3. Densities of frequent soil fauna groups of the flood experiment of the hillocks (A) and of the depressions (B), given as mean individual number per $\mathrm{m}^{2}(\mathrm{n}=10 ; \pm \mathrm{SD})$. C, control; $\mathrm{F}$, flood; $15,30,60$ and 90 , duration of flood (days); ${ }^{\mathrm{p}} \leq 0.05 ;{ }^{* *} \mathrm{p} \leq 0.01$ (MannWhitney U-test), significance in comparison with the respective flood versus control value under the same flood duration. 
Schaefer $(2005,2006)$ in flooding experiments in a comparable floodplain forest in Central Europe, where only grass- and leafhoppers could survive a periodic winter inundation in the egg stage, in which it was possibly dormant. Other invertebrate groups such as Araneae and carabid beetles did not survive flooding but migrated from nonflooded sites after inundation (Rothenbücher $\&$ Schaefer, 2006). As mentioned above, compared with data from the hillock control plots, the frequency of soil animals in the control plots located in the depressions was lower (Figure $3 \mathrm{~B}$ ). This indicates that the hillocks might be the preferred habitation of the macrofauna, due to the fact that the herbaceous plant layers of the hillocks offer more niches for the different soil fauna groups. However, since some individuals of nearly every soil fauna group were found in the flood plots of the depressions, it seems justified to assume that they can survive at least certain periods of total flooding. This suggests a better adaptation of the different soil fauna groups found at the depressions to flood events based on the two partial floods, whereas the hillocks remained dry since the extremely hot and dry summer of 2003.

Generally, the abundance of the macrofauna groups could be categorized as marginal. This low number of individuals was probably caused by the chosen STAFD-tube diameter of $7.0 \mathrm{~cm}$. Greater abundance of macrofauna may have resulted from the $15 \mathrm{~cm}$ diameter.

However, the density of mesofaunal groups like Acari and Collembola are comparatively high (Collembola flood: 1,000-17,000 individuals $\mathrm{m}^{-2}$; control: 15,00032,000 individuals $\mathrm{m}^{-2}$ ). According to these data, the STAFD method appears effective for the simulation of flooding. This is also demonstrated by the water content of the flooded plots, being nearly twice as high as the control. (Table 1).

Table 1. Mean \pm SD water content (\%) of the flood and control plots $(\mathrm{n}=10)$ after 15, 30, 60 and 90 days.

\begin{tabular}{lcc}
\hline Days & \multicolumn{2}{c}{ Water content (\%) } \\
\cline { 2 - 3 } & Flood & Control \\
\hline 15 & $41.1 \pm 5.7$ & $21.0 \pm 3.2$ \\
30 & $43.0 \pm 5.8$ & $22.6 \pm 3.7$ \\
60 & $52.5 \pm 7.1$ & $24.6 \pm 2.9$ \\
90 & $48.1 \pm 5.4$ & $29.7 \pm 3.9$ \\
\hline
\end{tabular}

\section{Artificial drought experiment}

The reduced water content of the drought plots confirmed the serviceability of the STAFD method, but the recovery of soil animals depended on the extraction method (Table 2). For example, wet sieving and the Kempson extraction produced comparable numbers of isopods. However, wet sieving produced significantly higher numbers of enchytraeids $(\mathrm{p}<0.01$, U-test, for all samples) and nematodes $(p<0.05$ and $p<0.01, U$-test, for different samples and durations) (Figures 4 and 5), whereas Coleoptera larvae ( $\mathrm{p}<0.01$, U-test, for 120-day duration) and Lithobiomorpha $(\mathrm{p}<0.05$, U-test, for 120-day duration) were extracted more efficiently by the Kempson method. For other groups, it is possible that the wet sieving itself broke egg dormancy.

After 30 days of drought, only the wet sieving procedure was carried out, because of technical problems with the heating unit of the Kempson extractor. There were no significant differences between the drought and control plots after wet sieving, and the densities of the soil fauna groups were comparable between them after 60 days of drought. After 90 and 120 days of drought, the first dropouts of some soil faunal groups, especially after wet sieving were seen, but for a significant difference between the drought and the control plots, the duration of the drought should be longer. At $0-5 \mathrm{~cm}$ depth, soil water content of the drought soil treatment averaged 10\% lower than the control. Contrary to the expectation that with increasing length of drought the water content would decrease, no reduction greater than $10 \%$ was observed. At $15-20 \mathrm{~cm}$, the reduction of water content was even less, averaging only $3-4 \%$ lower in comparison to the control. This also raises the question of whether the tube insertion method adequately simulates the effects of drought in such a "short" duration of 120 days. For the drought experiment, further and more prolonged investigations are necessary to solve this issue.

Table 2. Mean $( \pm \mathrm{SD})$ water content $(\%)$ of the drought and control plots $(\mathrm{n}=10)$ at two depths after 60,90 and 120 days.

\begin{tabular}{|c|c|c|c|c|c|c|}
\hline \multirow[t]{2}{*}{ Depth } & \multicolumn{2}{|c|}{60 days } & \multicolumn{2}{|c|}{90 days } & \multicolumn{2}{|c|}{120 days } \\
\hline & Control & Drought & Control & Drought & Control & Drought \\
\hline $0-5 \mathrm{~cm}$ & $56.1 \pm 19.2$ & $24.9 \pm 5.6$ & $34.7 \pm 4.3$ & $26.7 \pm 6.3$ & $38.5 \pm 7.5$ & $25.8 \pm 14.2$ \\
\hline $15-20 \mathrm{~cm}$ & $25.8 \pm 9.4$ & $21.0 \pm 3.5$ & $24.5 \pm 4.3$ & $22.2 \pm 2.6$ & $21.8 \pm 4.4$ & $22.9 \pm 3.7$ \\
\hline
\end{tabular}



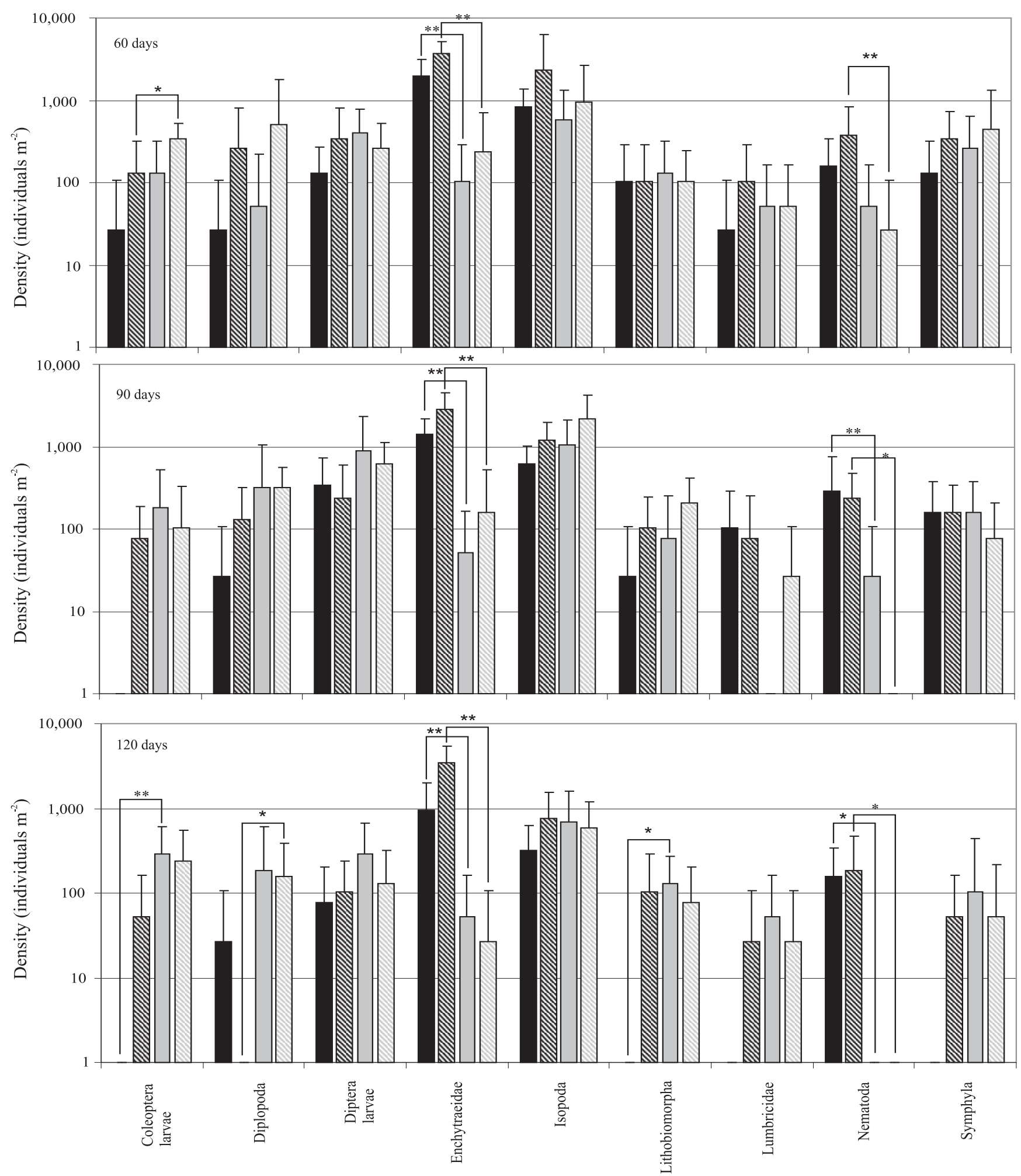

Drought experiment hillocks

Wet sieving drought Wet sieving control

$\square$ Kempson drought

Kempson control

Figure 4. Densities of frequent soil fauna groups after 60,90 and 120 days of simulated drought of the hillocks, given as mean individual number per $\mathrm{m}^{2}(\mathrm{n}=10 ; \pm \mathrm{SD}) .{ }^{*} \mathrm{p} \leq 0.05 ;{ }^{*} \mathrm{p} \leq 0.01$ (Mann-Whitney U-test), significance in comparison with the respective wet sieving versus Kempson extraction value under drought as well as control conditions. 

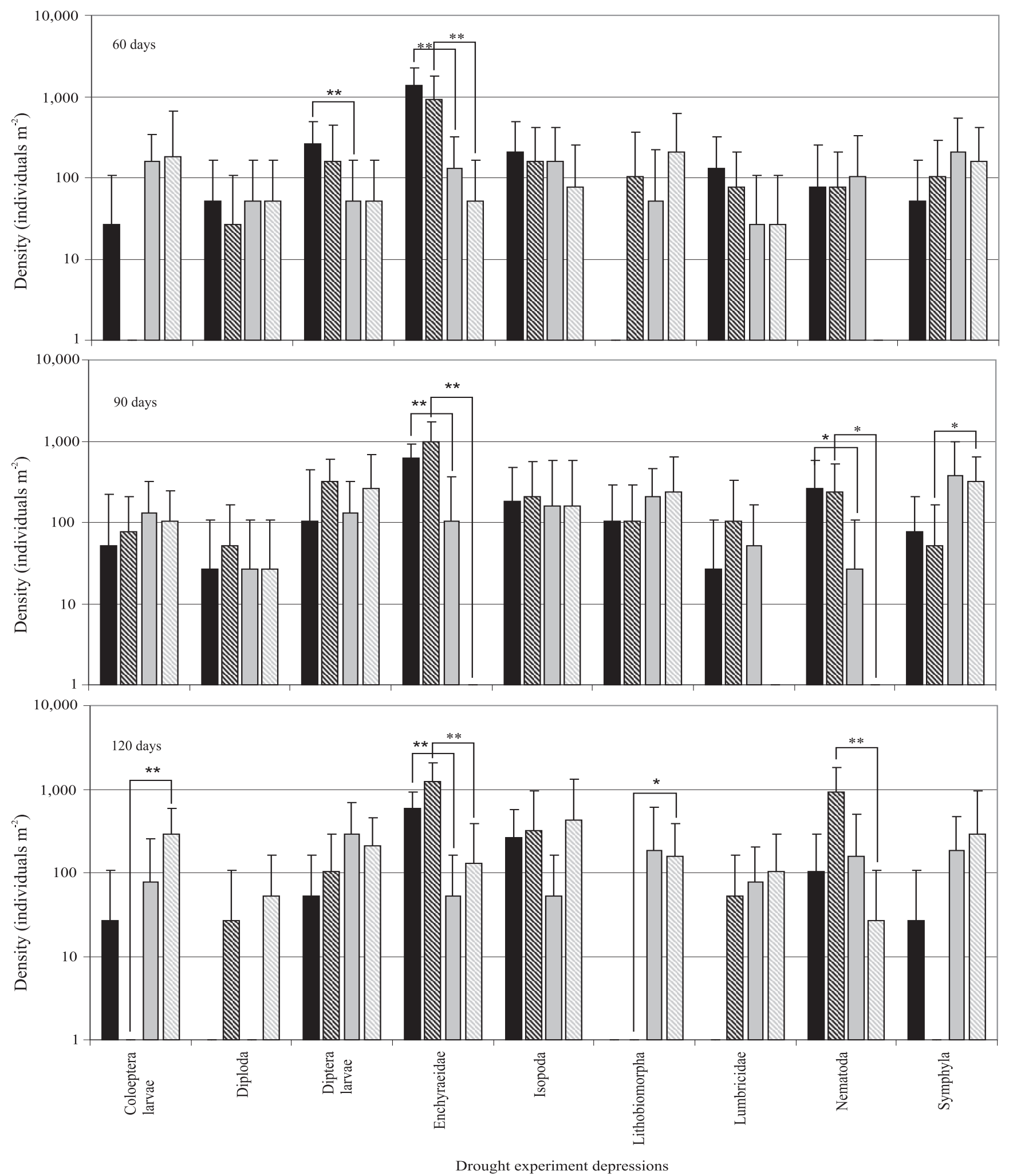

Wet sieving drought

Wet sieving control

$\square$ Kempson drought

Kempson control

Figure 5. Densities of frequent soil fauna groups after 60, 90 and 120 days of simulated drought of the depressions, given as mean individual number per $\mathrm{m}^{2}(\mathrm{n}=10 ; \pm \mathrm{SD}) .{ }^{*} \mathrm{p} \leq 0.05 ; * * \mathrm{p} \leq 0.01$ (Mann-Whitney U-test), significance in comparison with the respective wet sieving versus Kempson extraction value under drought as well as control conditions. 


\section{Conclusions}

1. Soil tubes for artificial flood and drought (STAFD) method can be used for assessing the effects of environmental changes (flood and drooght) in natural habitats over periods of up to 120 days, whereas the drought experiment needs more prolonged investigation times.

2. The method is very cheap, wich allows for a larger sample size and subsequent statistical analysis and could be modified for other investigations with minimal disturbance of the environment.

\section{Acknowledgements}

To David Bignell, for the very helpful comments and linguistic revision, as well as Carlos Mora-Ferrer, for the valuable assistance. The project was supported by the Centre of Environmental Research and the Feldbausch Foundation of the Johannes Gutenberg University of Mainz.

\section{References}

ADIS, J. Überlebensstrategien terrestrischer Invertebraten in Überschwemmungswäldern Zentralamazoniens. Verhandlungen des Naturwissenschaftlichen Vereins Hamburg, v.33, p. 21-114, 1992.

ELLENBERG, H. Vegetation Mitteleuropas mit den Alpen in ökologischer, dynamischer und historischer Sicht. Stuttgart: Verlag Eugen Ulmer, 1996. 1095p.
FRAMPTON, G.K.; BRINK, P.J. van den; GOULD, P.J.L. Effects of spring drought and irrigation on farmland arthropods in southern Britain. Journal of Applied Ecology, v.37, p.865-883, 2000.

KEMPSON, D.; LLOYD, M.; GHELARDI, R. A new extractor for woodland litter. Pedobiologia, v.3, p.1-21, 1963.

KUNDZEWICZ, Z.W.; ULBRICH, U.; BRÜCHER, T.; GRACZYK, D.; KRÜGER, A.; LECKEBUSCHE, G.; MENZEL, L.; PINSKWAR, I.; RADIEJEWSKI, M.; SZWED, M. Summer floods in central Europe - climate change track? Natural Hazards, v.36, p.165-189, 2005.

LINDBERG, N.; ENGTSSON, J.B.; PERSSON, T. Effects of experimental irrigation and drought on the composition and diversity of soil fauna in a coniferous stand. Journal of Applied Ecology, v.39, p.924-936, 2002.

MORRIS, H.M. On a method of separating insects and other arthropods from the soil. Bulletin of Entomological Research, v.8, p.197-199, 1922.

ROTHENBÜCHER, J.; SCHAEFER, M. Conservation of leafhoppers in floodplain grasslands: trade-off between diversity and naturalness in a Northern German National Park. Journal of Insect Conservation, v.9, p.335-349, 2005.

ROTHENBÜCHER, J.; SCHAEFER, M. Submersion tolerance in floodplain arthropod communities. Basic and Applied Ecology, v.7, p.398-408, 2006.

SCHÄR, C.; VIDALE, P.L.; LÜTHI, D.; FREI, C.; HÄBERLI, C.; LINIGER, M.A.; APPENZELLER, C. The role of increasing temperature variability in European summer heatwaves. Nature, v.427, p.332-336, 2004.

SCHRÖTER, D.; ZEBISCH, M.; GROTHMANN, T. Climate change in Germany - vulnerability and adaptation of climatesensitive sectors. Klimastatusbericht, v.2005, p.44-56, 2005.

TAMM, J.C. Temperature-controlled under-water egg dormancy and postflood hatching in Isotoma viridis (Collembola) as forms of adaptation to annual long-term flooding. Oecologia, v.68, p.241-245, 1986.

Received on January 6, 2009 and accepted on June 14, 2009 